\title{
Pancheshwar Multipurpose Project: Nepal's Portion of Power
}

\section{SB Pun}

Abstract: After the proverbial 13 year 'ban bas', the 1996 Mahakali treaty was "re-activated" in 2009 when Nepal and India constituted the Pancheshwar Development Authority to finalize the Detailed Project Report of Pancheshwar Multipurpose Project and thereafter undertake the execution, operation and maintenance of the project. In this context, the article reverts back to the ratification time of the Mahakali treaty in 1996 and dwells exclusively on the issues then raised pertaining to Nepal's portion of power from Pancheshwar project. The then prime minister and water resources minister gave CPN-UML party general secretary and the CPN-UML Mahakali study team coordinator written replies (a) on India being "forced to buy" Nepal's portion of power, (b) that "relevant alternatives" meant "thermal and gas plants and excludes hydropower plants", and iii) that "savings in cost to the beneficiaries as compared with the relevant alternatives" meant the same as "avoided cost of alternative principle." No attempts were made to elicit the Government of India's interpretations on these vital issues. Instead, while the water resources minister claimed Rs 21 billion annually from the sale of Nepal's portion of Pancheshwar power to India, the not-to-be outwitted party secretary claimed an astronomical annual revenue of Rs 120 billion. The now incumbent prime minister has come up with another attractive figure of Rs 45.88 billion annually. The article attempts to point out that if due diligence is not undertaken immediately on the ambiguities prevailing in the Mahakali treaty and the letters of exchange, then Nepal may well end up as like Paraguay vis-a-vis Brazil on the 14,000 MW Itaipu hydropower project.

Key words: Pancheshwar Multipurpose Project, Mahakali treaty, avoided cost, power revenues, Nepal

\section{Foreword}

T Tith the formation of the Pancheshwar Development Authority ${ }^{1}$ in November 2009, the Mahakali treaty has finally emerged from its 13 year long 'gupta ban bas.' The 6,720 Megawatt Pancheshwar Multipurpose Project ${ }^{3}$ (PMP) with an annual average energy of 12,333 million units and a live storage of 6.56 billion cubic meter of fresh water is the principal flagship of the Mahakali treaty. The "equal entitlement in the use of Mahakali waters without prejudice to their respective consumptive uses means equal rights to all the waters of Mahakali"4 and the "half-half sharing"5 of the 6.56 billion cubic meter of Mahakali fresh water have, it appears, been given decent burials. Buried also is the "precludes the claim" 6 , in any form, by either Party on the unutilized portion of the shares ${ }^{7}$ [3.28 billion cu. m.] of the waters of the Mahakali", as this fails to register on Nepalese radars. What does register regularly and prominently on the Nepalese radars is Nepal's annual portion of 6,160 million units of electricity destined for export to India. Despite being availed 13 years of "gupta ban bas" for genuine soul searching, Nepal continues its Panchayat era strategy gobbling, hook line and sinker, the 'get rich quick' export bait without due diligence. It is, therefore, imperative that the general Nepalese be acquainted with the subtleties and nuances of the Mahakali treaty and the various official and un-official interpretations regarding the export of Nepal's portion of Pancheshwar power.

\section{Mahakali Treatyand Letters of Exchangeon Pancheshwar Power}

The following are the exact wordings of the Mahakali Treaty and the Letters of Exchange on the electricity to be produced by the Pancheshwar Multipurpose Project: ${ }^{8}$

\section{Article 3, Clause 3 of Mahakali Treaty}

"A portion of Nepal's share of energy shall be sold to India. The quantum of such energy and its price shall be mutually agreed upon between the Parties."

\section{Item 3(a) of the Letters of Exchange}

"While assessing the benefits from the Project during the preparation of the DPR, net power benefit shall be assessed on the basis of, inter alia, saving in costs to the beneficiaries as compared with the relevant alternatives available."

\section{'Dohari' Between Coordinator K.P. Sharma (Oli) and Minister Pashupati S.J.B. Rana Just Prior to Ratification of Mahakali Treaty on September 20, 1996}

The following are the questions (of August 19, 1996 and August 25, 1996) of K.P. Sharma (Oli), Coordinator of CPNUML's Mahakali Treaty Study Team and the answers (of August 22, 1996 and August 27, 1996) provided by Pashupati SJ B Rana, the then Minister for Water Resources on Nepal's portion of Pancheshwar power for export to India. ${ }^{9}$

\section{Coordinator, K.P. Sharma (Oli)}

"Does the treaty's provision that Nepal sell electricity to India create a situation whereby Nepal is forced and India has choice?"

\section{Minister Pashupati SJ B Rana}

"Article 3, Clause 4 of the Mahakali Treaty states that a portion of Nepal's share of energy shall be sold to India and not the entire amount. Nepal's portion of electricity from the Pancheshwar Project is about five arab 30 crore [c. 5.3 
billion] units annually. As such large amount of electricity cannot be consumed internally, it is in Nepal's interest to provision some amount for sale to India. But as the treaty's same clause has stipulated a mutually agreed quantum and price of electricity, this will not createa choice for India. Both parties are equally bound by the mutually agreed quantum and price. Besides, as both parties have signed the treaty, when Nepal sells electricity India will be automatically bound to buy."

\section{Coordinator, K.P. Sharma (Oli)}

"On what principle is the price of Nepal's electrical energy to be sold to India determined? And where and how has this principle been incorporated in the treaty? Is 'savings in cost to the beneficiaries as compared with the relevant alternatives' as stipulated in the treaty applicable in this case? And does this mean the same as 'avoided cost principle?"”

\section{Minister Pashupati SJ B Rana}

"To determine the price of electrical energy, various principles like cost-plus, avoided cost of alternatives, willingness to pay and resources usetax areused. Amongthese, except for the 'avoided cost of alternatives' the wordings in the assessment of power benefit in Item 3(b) of the treaty's Letters of Exchange do not agree with the other three principles. In other words 'savings in cost to the beneficiaries as compared with the relevant alternatives' and 'avoided cost of alternative principle' mean the same. The Columbia River Treaty of 1959AD between America and Canada used the same kind of language for the same purpose..$^{10}$ Based on the evaluation of this benefit and the individual share, the price of electricity export will be determined. As per the treaty's Article 12, Clause 4, this will be provisioned in a separate Pancheshwar Project agreement."

\section{Coordinator, K.P. Sharma (Oli)}

"The answer refers to Item 3 of the Letters of Exchange of the treaty. The wordings of the letter are for assessing the benefit of the Pancheshwar Project and not for determining the energy price that Nepal sells to India. To question 8, you had answered that while interpreting the wordings of the treaty this should not be done independently but in the context. The answer to question 13 is not in this spirit. Is it logical to consider the answer to question 8 'within the limited context' while with regard to question 13 'to come out of the context'? What do you have to say on this?"

\section{Minister Pashupati SJ B Rana}

"What was said is that the wordings of Item 3's second sub-item of the treaty's Letters of Exchange, being tied with Article3 of thetreaty, mustnotbeinterpreted independently. So it is all right to look within the limited context in reply to question-8. But since no article or context is tied with
Item 3(a) of the Letters of Exchange of the treaty, it is not necessary in the case of question 13 to view within a limited context."

Prime Minister SB Deuba's answer11 to CPN-UML General Secretary M.K. Nepal

The treaty's provision, that a portion of Nepal's share of energy shall be sold to India with thequantum of such energy and its price mutually agreed between the two parties, forces India to buy Nepal's power. This is automatic and clear! Saving in costs of energy as compared with generation from other alternative sources (like thermal plant, gas turbine etc.) excluding hydropower will be the basis for determining electricity price. This is called the avoided cost principle on which the government is clear.

\section{Comments on the 'Dohari': \\ On "when Nepal sells electricity, India will be automatically bound [forced] to buy"}

K.P. Sharma (Oli) had misgivings with the wordings of the treaty and hence asked that shrewd question whether a situation is created "whereby Nepal is forced and India has choice" in buying Nepal's portion of Pancheshwar power. With the benefit of hindsight, it is now difficult to believe how Water Resources Minister Rana could have given such a simplistic but convoluted reply "as both parties have signed the treaty, when Nepal sells electricity India will be automatically bound to buy."

Equally convoluted is Prime Minister Deuba's logic that as the quantum of energy and its price are "mutually agreed upon," the treaty "forces India to buy Nepal's power." Such "automatically bound to buy" and "forces India to buy Nepal's power" psyche of the Deuba government prevails to this day in all successive governments of Nepal. No attempt whatsoever has been made to elicit the Government of India's official interpretation on this vital issue. As argued by Prime Minister Deuba and his Minister Rana, if the quantum and price of energy are mutually agreed upon by both the parties, then there is no question of one party being forced to buy another's portion of energy. On the other hand, however, if India does not agree with either the price or quantum of energy, Prime Minister Deuba and Minister Rana fail to explain to the parliament and the Nepalese what would construe in that case. Observers believe that India, as the one and only buyer, has the upper hand to dictate the 'mutually' acceptable price. Thus, K.P. Sharma (Oli)'s apprehension "whereby Nepal is forced and India has choice" is not incorrect!

\section{On "as compared with the relevantalternatives available"}

Both Prime Minister Deuba and Water Resources Minister Rana insisted that 'generation from other alternative sources (like thermal plant, gas turbine etc.) excluding hydropower will be the basis for determining 
electricity price'. They sanguinely presumed that, with over $66 \%$ of India's power generation is thermal based, the Government of India's interpretation would be the same as their own. Being in extreme haste to ratify the treaty, they did not deem it necessary to get the Government of India's official interpretation of the "relevant alternatives available."

Instead, in the immediate aftermath of the Mahakali Treaty ratification, Minister Rana claimed at a press meet on Ashwin 7, 2053 (September 23, 1996 AD) that Nepal would earn from the Pancheshwar Project an average of Rs 21 billion annually from export of electricity alone. ${ }^{12}$ Foreign Minister Dr P.C. Lohani was more confident, explaining that even if the Pancheshwar electricity was sold at 6 or 7 US cents per unit, based on the treaty's principle of saving in costs as compared with the alternatives, Nepal's net electricity export would be over Rs 24 billion per annum. ${ }^{13}$ The economist that he was, Dr Lohani calculated that after deducting all expenses like principal, interest, operation and maintenance, etc., Nepal would still earn revenues of between Rs 10 to 12.5 billion annually. The shrewd K.P. Sharma (Oli), not to be outflanked by the 'political dividends' of Mahakali treaty, rolled out an astronomical figure $^{14}$ of Rs 120 billion annually! After the lapse of 13 years Dilli Bahadur Singh, the present Pancheshwar Project chief, reeled ${ }^{15}$ out an equally handsome figure of Rs 45.88 billion annually. His logic-to sell Nepal's portion of energy to India at the rate Nepal Electricity Authority presently buys at Rs 5.60 per unit. In fact, so popular has this figure of Rs 45.88 billion become that even Prime Minister M.K. Nepal and his ministers flourish it in their public speeches. Observers wonder whether D.B. Singhs's Rs 5.60 per unit is a "mutually agreed" (i.e., forced to buy) figure with India or mere Som Sharma's sattu dreams?

R.R. Iyer, the erudite former Water Resources Secretary in the Government of India, argued that thermal and gas plants "need not be assumed to be the only alternatives available."16 This is clearly counter to what Prime Minister Deuba wrote in his August 1996 reply to CPN-UML General Secretary M.K. Nepal: that "Saving in costs of energy as compared with generation from other alternative sources (like thermal plant, gas turbine etc.) excluding hydropower will be the basis for determining electricity price." This is called the avoided cost principle on which the government is clear. Similarly Water Resources Minister Rana wrote to Coordinator K.P. Sharma (Oli) in August 1996 confirming in other words that "savings in cost to the beneficiaries as compared with the relevant alternatives" and "avoided cost of alternative principle" mean the same. Foreign Minister Dr Lohani was more equivocal, stating that even if the "Pancheshwar electricity was sold at 6 or 7 US cents per unit, based on the treaty's principle of saving in costs as compared with the alternatives..." the Government of India has shrewdly kept this issue within its chest, uttering not a word!

\section{On for "assessing the benefit and not for determining} the energy price"

Due credit must be given to Coordinator K.P. Sharma (Oli) who in his questions of August 25, 1996 to Minister Rana informed "the wordings of the letter are for assessing the benefit of the Pancheshwar Project and not for determining the energy price that Nepal sells to India." This was definitely not the interpretations of Ministers Rana and Lohani who have publicly rolled out the figures of Rs 21 billion and Rs 24 billion per annum. There are already some Nepalese who talk in the same wavelength as K.P. Sharma (Oli). Indeed it is now imperative for Nepal to get India's official interpretation on whether she is in line with Minister Rana or Coordinator Oli. Despite thelapse of 13years, Nepal has made no attempts to unravel and fathom what "the alternatives available" actually means. Former Secretary R.R. Iyer further added that "if in fact the generation cost at Pancheshwar is lower, the gain would surely have to be shared between the two countries..." ${ }^{17}$ One cannot dispute this statement of his either!

\section{Lessons from Paraguay/Brazil's 14,000 MW Itaipu Binational Hydroelectric Project ${ }^{18}$}

In 1973 the tiny land-locked country of Paraguay signed the Itaipu Treaty with her large next door neighbor, Brazil, to construct the world's (then) largest 12,600 MW Itaipu Hydroelectric Power Plant on the border river, Parana. The first $700 \mathrm{MW}$ unit was commissioned in 1984 and the last 18th unit in 1991. The initial estimated cost of US\$2 billion skyrocketed to US $\$ 18$ billion by the time of completion. The Itaipu Dam was heralded as a triumph of cross-border cooperation on water resources development between a large and small neighbor.

In 2008 Itaipu generated a record 94,600 million units of energy of which Paraguay is entitled half by the treaty. Over the last two decades Itaipu's average annual generation has been about 82,000 million units and Paraguay's half share is a huge 41,000 million units per year. In comparison, Pancheshwar with Rupaligad would generate a humble total of 12,333 million units annually and Nepal's half would only be about 6,200 million units. Like Nepal's projected sale of Pancheshwar power to India, Paraguay sells over $90 \%$ of her Itaipu power to Brazil. Despite selling such a huge amount of energy (over six times of Nepal's projected Pancheshwar sale) for over two decades, Paraguay continues to be the second poorest country, after Bolovia, in Latin America. The reason: Brazil was "forced to buy" Paraguay's Itaipu power at a "mutually agreed price" of US0.42 cents per unit that has provided Paraguay a paltry annual revenue of about US\$170 million only!

Hence, Paraguay's new left-leaning President Fernando Lugo has called for renegotiation of the 1973 Itaipu Treaty. President Lugo is demanding a fair price and the right to sell directly to Brazilian distributors or to Argentina and Chile, 
two other South American countries that have recently faced energy shortages. WhileParaguay's biggestnewspapercalled Brazil an "imperialist and exploiter", J orge Lara Castro, the Deputy Foreign Minister of Paraguay, summed it up as this: "At stake is the viability of a poor country... the realpolitik of an ant staring up at an elephant." Nepal, like that ant staring up at an elephant, should note that the Itaipu Treaty stipulated that Paraguay cede its unused electricity share only to Brazil's Rio deJ aneiro-based Electrobas, the largest utility company in Latin America. Paraguay's director at Itaipu, Carlos Mateo Balmelli, in an interview, said "We are not looking for a gift or any concession other than allowing market forces to work."

\section{Final Word: Landing on the Same Frying Pan as Paraguay?}

Due to the subtleties and legal nuances inherent in the treaty, the then Prime Minister Deuba and his Minister Rana had their own "forced to buy" interpretations on Nepal's portion of Pancheshwar power. Even knowledgeable Nepalese are confused about the "alternatives available"-whether this is (according to Prime Minister Deuba) limited to "thermal and gas plants" only, or if it includes (according to India's exSecretary R.R. Iyer) "other hydro-plants" as well. K.P. Sharma (Oli) has not failed to point out that "...net power benefit shall be assessed on the basis of, inter alia, saving in costs to the beneficiaries as compared with the relevant alternatives available..." is for assessing the benefit of the Pancheshwar Project and not for determining the energy price.

Water Resources Minister Rana and Foreign Minister Dr Lohani, both of whom were privy to intimate behindthe-scene negotiations, think otherwise however. They have publicly stated to the Nepalese people that the annual revenues accruing to Nepal from sale of Pancheshwar power would be Rs 21 billion and Rs 24 billion respectively. The confusion has been further compounded by the incumbent Prime Minister M.K. Nepal doubling this figure to Rs 45.88 billion per annum. ${ }^{19}$ Note that Brazil ensured that Paraguay ceded its unused Itaipu power to a Brazil designated utility only. Paraguay was not given the option to sell her unused power either to Argentina or even to other distributors within Brazil itself. Such a scenario is not unlikely in Nepal's portion of Pancheshwar power. The Government of India has designated the Power Trading Corporation of India as the single nodal agency through which all Nepal-India power transactions need to be routed. ${ }^{20}$

Numbed by the "apar khera gai rakheko pani" (infinite waste of water), Nepal's political masters suffer acutely from the propensity to count the chickens before they are hatched. Nepal needs to smoothen and rectify, if necessary, with due diligence the subtleties, nuances and ambiguities in the Mahakali treaty and the accompanying Letters of Exchange. ${ }^{21}$ The Norwegian, Odd Hoftun, who toiled over 40 years in the Nepalese power sector, calls Nepalese hydropower potential and Indian market "a blessing as well as a curse." Hoftun believes that Nepal should implement large multipurpose projects, but cautions "Nepal should not rush into it." ${ }^{\prime 22}$ According to him, to implement big projects "there has to be a fair agreement and a very high level of trust between the two nations...' This is the advice of a true friend of Nepal. It is unlikely, in the din and noise of the present 'transitional' politics, that our political masters can hear that sincere advice. One can only hope and pray that, in the end, Nepal does not land in the same frying pan as Paraguay!

Sant Bahadur Pun is the former Managing Director of Nepal Electricity Authority, Nepal and in his closing years he served as Officer on the Special Duty at the Ministry of Water Resources, Government of Nepal. He writes on water and energy issues.

Corresponding Address: santapun@ntc.net.np

\section{Notes}

1. www.moe.org.np. The Secretary level J oint Committee on Water Resources (JCWR) meeting held between Nepal and India at Pokhara on November 2009.

2. 'Gupta banbas' is a Nepali saying that refers to the 13 year punishment (1 yr as to live secretly) in the forest that was imposed on the Pandavs by the Kauravs in the Mahabharat epic.

3. 6,480 MW and 10,671 million units at Pancheshwar and $240 \mathrm{MW}$ and 1,662 million units at Rupaligad (see the Pancheshwar Multipurpose Project: Detailed Project Report, Nepal Ministry of Water Resources, Electricity Development Center, November 1995).

4. This is one of the four strictures (sankalpas) passed by the J oint Session of the two Houses of Nepalese Parliament at the time of ratifying the Mahakali Treaty on September 20, 1996.

5. The treaty states "equal entitlements... without prejudice to their respective consumptive uses." The then CPN-UML General Secretary (now the incumbent Prime Minister), Madhav Kumar Nepal, unequivocally interpreted at treaty ratification time (September $20,1996)$ that "equal entitlements means half-half' sharing of Mahakali waters irrespective of the "existing consumptive uses."

6. This biggest Nepalese blunder (in the writer's view) is conveniently embedded in the Letters of Exchange and not in the more prominent Treaty itself.

7. Nepal's share, besides the Mahakali's transit flows, would be 3.28 billion cubic meter of fresh water.

8. Official publication of the Ministry of Water Resources, His Majesty's Government of Nepal dated Kartik 29, 2053 (Nov. 14, 1996) on the Treaty between His Majesty's Government of Nepal and the Government of India concerning the Integrated Development of the 
Mahakali River including Sarada Barrage, Tanakpur Barrage and Pancheshwar Project.

9. Thequestions of K.P. Sharma(Oli), coordinator of CPNUML Mahakali Treaty Study Team, and the answers of Pashupati S.J .B. Rana, Water Resources Minister, have been extracted and translated into English from the official publication in Nepali of the Ministry of Water Resources, Government of Nepal dated Kartik 29, 2053 (November 14, 1996AD) on the Treaty Between His Majesty's Government of Nepal and the Government of India Concerning the Integrated Development of the Mahakali River including Sarada Barrage, Tanakpur Barrage and Pancheshwar Project. (In the statements of the respective interlocutors, the emphasis in italics has been added by the author.)

10. The Columbia River Treaty was actually signed on January 17, 1961. Minister Rana's reference to 1959 must be the report submitted in March 1959 by the International Columbia River Engineering Board (ICREB) to the International Joint Commission of the Governments of Canada and the United States of America-Booklet of British Columbia Hydro and Power Authority, October 1964.

11. The September 11, 1996 written answers of Prime Minister SB Deuba to CPN-UML General Secretary M.K. Nepal's letter of September 10, 1996 (note within just one day! - writer) are extracted in toto and translated into English from the official publication in Nepali of the Ministry of Water Resources, His Majesty's Government of Nepal dated Kartik 29, 2053 (Nov. 14, 1996) on the Treaty Between His Majesty's Government of Nepal and the Government of India Concerning the Integrated Development of the Mahakali River Including Sarada Barrage, Tanakpur Barrage and Pancheshwar Project

12. Op. cit., footnote 8.

13. Ibid.
14. Dhruba Kumar, 'Parliament and public policy making: A case study of the Mahakali Treaty' in Dr Lok Raj Baral, ed., Nepal Political Parties and Parliament, New Delhi: Adroit Publishers (2004).

15. Kantipur(Kathmandu, Nepalilanguagedaily), Shrawan 29, 2066 (August 13, 2009). According to D.B. Singh, the annual benefits to Nepal from Pancheshwar were electricity: Rs 45.88 billion; irrigation: Rs 5.69 billion; fisheries: Rs 16 billion; and carbon credit: Rs 4.42 billion, resulting in a whopping annual benefit of Rs 71.99 billion! There was no mention of benefits to India which are, as usual, conveniently kept under wraps.

16. R.R. Iyer, 'Delay and drift on the Mahakali', Himal South Asia magazine (Kathmandu, J une 2001).

17. Ibid.

18. Itaipu's initial installed capacity of $12,600 \mathrm{MW}$ made it the world's largest hydroelectric power station until China's 22,500 MW Three Gorges Project surpassed it. Two more units were added at Itaipu in 2007 to raise its installed capacity to $14,000 \mathrm{MW}$.

19. Prime Minister M.K. Nepal is merely parroting the figures of D.B. Singh, the present Pancheshwar Project Chief, who when asked whether his figures were official or not replied that they were personal.

20. Nepal's present power import, in excess of the $50 \mathrm{MW}$ Power Exchange, is all routed through this Power Trading Corporation of India. Such a nodal agency is useful to the Government of India to keep a close tab on all Nepal-India power sector activities.

21. For instance, the four sankalpas (strictures) of the Nepalese Parliament passed on September 20, 1996.

22. Shiva Bista, 2009, 'Odd Hoftun's perspective on hydropower development in Nepal', Hydro Nepal No.5, p.61 (emphasis added).•

\section{GALL FOR PAPERS}

The journal HYDRO Nepal is published twice in a year in J anuary and J uly by Media for Energy Nepal (Pvt.) Ltd, a sister concern of Environmental Resources Group Pvt. Ltd (eRG Nepal).

We call for articles and papers from professionals involved in the broad sectors of Water Resources, Energy and Environment, from the wide variety of experts in these fields such as: policy analysis, various use of water, hydropower and environmental engineering, the social and development sciences, economics, education, and the like. Our aim is to promote the exchange of ideas across all of these fields, in the pursuit of excellence and the sharing of experience and information in development.

Please refer to Authors Guidelines of HYDRO Nepal journal for detailed information in Url: www.erg.com.np 